\title{
Adiponectin, diabetes and ischemic heart failure: a challenging relationship
}

\author{
Samuele Baldasseroni ${ }^{1,2^{*}}$, Alessandro Antenore ${ }^{1,2}$, Claudia Di Serio ${ }^{1,2}$, Francesco Orso ${ }^{1,2}$, Giuseppe Lonetto ${ }^{1,2}$, \\ Nadia Bartoli ${ }^{1,2}$, Alice Foschini ${ }^{1,2}$, Andrea Marella ${ }^{1,2}$, Alessandra Pratesi ${ }^{1,2}$, Salvatore Scarantino ${ }^{1,2}$, \\ Stefano Fumagalli, ${ }^{1,2}$, Matteo Monamii ${ }^{1,2}$, Edoardo Mannucci ${ }^{1,2}$, Niccolò Marchionni ${ }^{1,2}$ and Francesca Tarantini ${ }^{1,2}$
}

\begin{abstract}
Background: Several peptides, named adipokines, are produced by the adipose tissue. Among those, adiponectin $(A D)$ is the most abundant. AD promotes peripheral insulin sensitivity, inhibits liver gluconeogenesis and displays anti-atherogenic and anti-inflammatory properties. Lower levels of AD are related to a higher risk of myocardial infarction and a worse prognosis in patients with coronary artery disease. However, despite a favorable clinical profile, AD increases in relation to worsening heart failure (HF); in this context, higher adiponectinemia is reliably related to poor prognosis. There is still little knowledge about how certain metabolic conditions, such as diabetes mellitus, modulate the relationship between AD and HF.

We evaluated the level of adiponectin in patients with ischemic HF, with and without type 2 diabetes, to elucidate whether the metabolic syndrome was able to influence the relationship between AD and HF.
\end{abstract}

Results: We demonstrated that AD rises in patients with advanced HF, but to a lesser extent in diabetics than in non-diabetics. Diabetic patients with reduced systolic performance orchestrated a slower rise of AD which began only in face of overt HF. The different behavior of AD in the presence of diabetes was not entirely explained by differences in body mass index. In addition, NT-proBNP, the second strongest predictor of AD, did not differ significantly between diabetic and non-diabetic patients. These data indicate that some other mechanisms are involved in the regulation of AD in patients with type 2 diabetes and coronary artery disease.

Conclusions: $A D$ rises across chronic heart failure stages but this phenomenon is less evident in type 2 diabetic patients. In the presence of diabetes, the progressive increase of AD in relation to the severity of LV dysfunction is hampered and becomes evident only in overt HF.

Keywords: Adiponectin, Diabetes, Coronary artery disease, Heart failure

\section{Background}

The adipose tissue should not be regarded as a simple site of lipid storage [1]; indeed it is able to secrete several peptides with hormonal properties that are involved in energy homeostasis as well as modulation of inflammation and regulation of many immunological mechanisms [2]. This heterogeneous group of hormones is named adipokines. Among these, adiponectin (AD) is by far the most abundant protein secreted by the adipose

\footnotetext{
*Correspondence: pesine@libero.it
'Department of Critical Care Medicine and Surgery, Geriatric Medicine Unit,

* Correspondence: pesine@libero.it
'Department of Critical Care Medicine and Surgery, Geriatric Medicine Unit, University of Florence, Florence, Italy 2Department of Heart and Vessels, Geriatric Cardiology and Medicine Unit,
University of Florence and Azienda Ospedaliero-Universitaria Careggi [AOUC ${ }^{2}$ Department of Heart and Vessels, Geriatric Cardiology and Medicine Unit,
University of Florence and Azienda Ospedaliero-Universitaria Careggi [AOUC], Viale Morgagni 85, 50134 Florence, Italy
}

tissue [3]. Although it is produced almost exclusively by adipocytes, plasma levels of AD are found to be inversely correlated to visceral adiposity and body mass index (BMI) [3]. AD promotes peripheral insulin sensitivity [4] and inhibition of liver gluconeogenesis [5]. As a matter of fact, hypoadiponectinemia is known to be the molecular link between obesity and insulin-resistance, at the base of metabolic syndrome [2]. AD is able to predict diabetes onset and diabetic patients always show lower plasma levels of AD compared to the general population [6]. In addition, it has been reported that plasma level of adiponectin in diabetic subjects with foot ulceration was lower than in diabetic subjects without diabetic foot [7], 
suggesting that hypoadiponectinemia may be related to the microvascular complications of diabetes.

Beside of its beneficial role in the glycometabolic pathway, AD shows several favorable properties as an antiatherogenic and anti-inflammatory agent [8]. Several studies report an AD mediated inhibition of many peptides and cytokines involved in the progression of atherosclerosis [9]. At the same time, AD seems to counteract the transition from stable atheromatic plaques to vulnerable ones [10]. Given these properties, it is not unexpected that hypoadiponectinemia is related to coronary artery disease (CAD) [11]. In fact plasma, levels of $\mathrm{AD}$ are able to predict not only the risk of myocardial infarction but also the prognosis and clinical course of CAD [10].

Because of all the beneficial effects on insulin resistance and atherosclerosis, it came as a surprise the observation that plasma levels of $\mathrm{AD}$ were elevated in chronic heart failure (HF) [12]. In fact, AD seems to increase in relation to worsening HF [13] and it is reliably related to poor prognosis [14]. Three main hypotheses have been proposed to explain this apparent paradox. The first one suggests that cachexia related to HF is responsible for the upsurge of $\mathrm{AD}$ [15]. A second hypothesis relates to the possibility of an adiponectin resistance: indeed, a lower density of $\mathrm{AD}$ receptors has been detected on musculoskeletal cells from HF patients [16]. The last suggestion came from an elegant study by Tsukamoto and coll. that showed how NT-proBNP is able to induce AD secretion from adipocytes. Furthermore, they found that injection of NT-proBNP in humans caused an increase in AD when compared to saline solution [17]. Based on an overall analysis of all data available, Park and coll. recently speculated that although high adiponectin levels may confer cardioprotection in the acute setting, i.e. during acute myocardial infarction, it may contribute in a permissive way to adverse remodeling in the post-acute period, accelerating the transition to heart failure [18].

Several factors are known to predict adiponectinemia; among those NT-proBNP and BMI are the most relevant [19]. However, little or nothing is known about how certain metabolic conditions, such as diabetes mellitus (DM), modulate the correlation between AD and HF.

Our aims were i) to evaluate plasma levels of $\mathrm{AD}$ in patients affected by ischemic HF with and without type $2 \mathrm{DM}$, ii) to analyze the correlation between adiponectinemia and ACC/AHA stage of chronic HF, and iii) to elucidate whether the presence of DM was able to influence the relationship between HF and AD levels.

\section{Methods}

\section{Study subjects}

We enrolled 150 consecutive outpatients referred to the Geriatric Cardiology and Medicine Unit of Careggi Academic Hospital (Florence, Italy) for CAD between January $1^{\text {st }}, 2008$ and December $31^{\text {st }}, 2010$. All patients were Caucasians and met the following inclusion criteria: written informed consent, CAD documented by at least one $\geq 75 \%$ stenosis of a major epicardial branch at coronary angiography, no hospitalization for worsening HF during the last two months. Those with type 2 diabetes were classified according to ADA criteria [20]. The study was approved by an institutional review committee.

\section{Clinical and instrumental data}

We collected a thorough clinical history, including symptoms needed to define New York Heart Association (NYHA) class. Patients underwent physical examination with measurement of height and weight to calculate BMI, 12-lead electrocardiogram, and 6-min walking test (6MWT) [21]. A standard echocardiographic study was carried out following the American Society of Echocardiography recommendations [22] using a 4-chamber apical view to calculate left ventricular ejection fraction (LVEF), according to the Simpson's formula. Heart failure was considered to be overt in the presence of positive European Society of Cardiology criteria [23], coupled with a Boston score $\geq 5$ [24]. As reported in the flow chart of Figure 1, the study population was divided into two groups: the diabetes (D) group which included patients with diagnosis of type $2 \mathrm{DM}$, and the non-diabetes (ND) group.

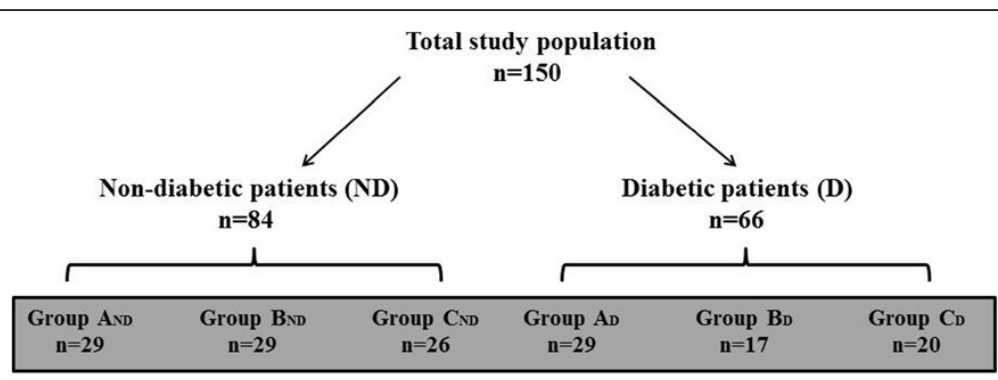

Patients classified as A, B or C according to ACC/AHA guidelines on chronic HF

Figure 1 Flow chart of the study. 
Combining LVEF with ESC and Boston criteria and according to ACC/AHA guidelines for chronic HF [25] each group was further divided into three subgroups as follows: group A including patients with LVEF $\geq 55 \%$, no overt HF; group B, LVEF $<40 \%$, no overt HF and group C, LVEF $<40 \%$, overt HF. Patients with LVEF in the $40-54 \%$ range were excluded from the study in order to select subjects with markedly different LV systolic function. Subgroups were marked as follows: $A_{N D}, B_{N D}$ and $C_{N D}$, including patients without diabetes, and $A_{D}$, $B_{D}$ and $C_{D}$ which comprised patients with type $2 \mathrm{DM}$ (Figure 1).

The level of non-cardiac comorbidity was measured with the Greenfield's Index of Disease Severity (IDS) score [26], whereas the presence of depressive symptoms was evaluated with the 30 -item form of the Geriatric Depression Scale (GDS) [27].

\section{Biochemical data}

Venous blood samples were drawn in the fasting state to detect glycaemia, hemoglobin $(\mathrm{Hb})$ and glycated $\mathrm{Hb}$ (HbA1c) which was analyzed by high liquid pressure chromatography (Menarini Diagnostics, Florence, Italy; upper normal limit 5.9\%). Glomerular filtration rate (eGFR) was estimated according to the Modification of Diet in Renal Disease (MDRD) Study method [28]. Plasma level of $\mathrm{AD}$ was determined, in duplicate, by ELISA (Linco Research, Missouri, USA); NT-proBNP was measured with a chemiluminescent immunoassay kit (Roche Diagnostic Laboratory, Indianapolis, IN, USA) on an Elecsys 2010 analyzer. All other biohumoral parameters are reported in Table 1.

\section{Statistical analysis}

Data were analyzed using SPSS $^{\circledR}$ software (version 17 ) and are presented as mean \pm SD or median (quartiles) - depending on their normal or non-normal distribution - for continuous variables, and as number (\%) for categorical ones. Categorical and continuous variables were compared between the two groups of patients (ND and $\mathrm{D}$ ) using the Pearson $T$-test and the chi-square test, respectively. The difference in $\mathrm{AD}$ plasma levels across the groups was analyzed as follows: first we used univariate ANOVA model to test the difference among the three ACC/AHA HF stage subgroups, separately in the ND and D group; then we compared the level of $\mathrm{AD}$ by coupling the matching stage of ND and D groups. Finally, BMI, NT-proBNP and HDL cholesterol were introduced in the univariate ANOVA models as covariates; this choice was supported by the fact that these three variables have proven to be the strongest predictors of $\mathrm{AD}$, as previously reported by us [19] and others $[3,13]$. In the last step, we tested different multivariate backward stepwise linear regression models with $\mathrm{AD}$ as dependent variable and age, gender, ACC/AHA HF stage, BMI, NTproBNP, HDL cholesterol and DM as independent variables, to test their independent predictive value.

\section{Results}

\section{Comparison between ND and D groups}

The main features of the study population and the main differences between the two groups (ND and D) are summarized in Table 1. Briefly, a history of angina and the presence of atrial fibrillation were slightly more prevalent among diabetics, although not significant. As expected glycaemia, HbA1c and BMI were significantly higher in group D patients, as well as smoking. We also noticed a worse performance at the 6MWT among diabetics which were also more likely to display peripheral edema despite a better mean LVEF. In accordance to the literature [29], pericardial fat tissue was thicker in diabetics because of their higher BMI. With the exception of clopidogrel and aldosterone blockers, drugs reported to be used were similar in the two groups; unexpectedly, statins were more frequently prescribed in the ND group. Among diabetics, 14 patients (21.2\%) were treated with diet alone, 14 (21.2\%) were prescribed metformin and $12(18.2 \%)$ a combination of two oral antidiabetic drugs. Twenty-six patients (39.4\%) were treated with insulin.

\section{Adiponectin}

Mean AD level was $9.7 \pm 7.3 \mathrm{ng} / \mathrm{ml}$ with a significantly higher level in the ND compared to the $\mathrm{D}$ group $(11.0 \pm 8.4$ vs $7.9 \pm 5.0 \mathrm{ng} / \mathrm{ml}, \mathrm{p}=0.012$ ) (Figure $2 \mathrm{~A}$ ). As shown in Figure $2 \mathrm{~B}$, there was a slight, but not significant, increase of $A D$ in group $B_{N D}$ compared to $A_{N D}$. $A$ significant rise was observed in group $\mathrm{C}_{\mathrm{ND}}$ compared to the other two $(\mathrm{p}=0.001$ and $\mathrm{p}=0.003$, respectively). Among diabetic subjects (Figure $2 \mathrm{C}$ ) no difference was found between $A_{D}$ and $B_{D}(6.8 \pm 4.2 \mathrm{ng} / \mathrm{ml}$ vs $6.3 \pm 4.7 \mathrm{ng} / \mathrm{ml}$, $\mathrm{p}=0.742$ ), while $\mathrm{C}_{\mathrm{D}}$ showed a significant increase $(11.0 \pm 5.1 \mathrm{ng} / \mathrm{ml})$ compared to both $\mathrm{A}_{\mathrm{D}}(\mathrm{p}=0.003)$ and $B_{D}(p=0.005)$. We finally matched subjects belonging to the same clinical stage of $\operatorname{HF}(\mathrm{A}, \mathrm{B}, \mathrm{C})$ but with different metabolic profile (ND vs. D) (Figure 3): no difference was found among diabetic and non diabetic patients in group A $\left(\mathrm{A}_{\mathrm{ND}} 7.4 \pm 4.7 \mathrm{ng} / \mathrm{ml}\right.$ vs. $\mathrm{A}_{\mathrm{D}} 6.8 \pm 4.2 \mathrm{ng} / \mathrm{ml}$, $\mathrm{p}=0.722$ ); $A D$ levels became significantly different in group $B\left(B_{N D} 10.7 \pm 9.3 \mathrm{ng} / \mathrm{ml}\right.$ vs. $B_{D} 6.3 \pm 4.7 \mathrm{ng} / \mathrm{ml}$, $\mathrm{p}=0.042)$ and even more divergent in group $C\left(C_{N D}\right.$ $15.3 \pm 8.8 \mathrm{ng} / \mathrm{ml}$ vs. $\left.C_{D} 11.0 \pm 5.1 \mathrm{ng} / \mathrm{ml}, \mathrm{p}=0.034\right)$.

When the analysis of variance of $\mathrm{AD}$ in different clinical stages of HF was adjusted for BMI, HDL cholesterol and NT-proBNP - the main cofactors known to predict AD plasma levels - the difference in AD still remained significant in the total population and in the ND group 
Table 1 Characteristics of the study population

\begin{tabular}{|c|c|c|c|c|}
\hline Variable & Total $n=150$ & ND Group n=84 & D Group $n=66$ & $\mathrm{p}$ value \\
\hline Age (years) & $68.8 \pm 10.8$ & $67.6 \pm 12.6$ & $70.2 \pm 7.6$ & 0.143 \\
\hline Female & $13 \%$ & $14 \%$ & $12 \%$ & 0.699 \\
\hline BMI $\left(\mathrm{Kg} / \mathrm{m}^{2}\right)$ & $26.7 \pm 4$ & $25.2 \pm 3.4$ & $28.8 \pm 4.2$ & 0.001 \\
\hline History of angina & $42 \%$ & $36 \%$ & $52 \%$ & 0.060 \\
\hline Previous ACS & $79.6 \%$ & $82 \%$ & $79 \%$ & 0.500 \\
\hline Previous PTCA & $75 \%$ & $73.6 \%$ & $80.1 \%$ & 0.307 \\
\hline Previous CABG & $27.6 \%$ & $27.3 \%$ & $28.8 \%$ & 0.921 \\
\hline Atrial fibrillation & $17.8 \%$ & $13.1 \%$ & $24.2 \%$ & 0.084 \\
\hline Hypertension & $69.7 \%$ & $66.7 \%$ & $75.8 \%$ & 0.267 \\
\hline Dyslipidemia & $69.7 \%$ & $70.2 \%$ & 71.2 & 0.986 \\
\hline Smoking & $63 \%$ & $51.2 \%$ & $80 \%$ & 0.001 \\
\hline COPD & $12.5 \%$ & $11.9 \%$ & $13.6 \%$ & 0.773 \\
\hline NYHA class III-IV & $19.4 \%$ & $15.5 \%$ & $13.6 \%$ & 0.982 \\
\hline Boston score & $2.5 \pm 3.4$ & $2.7 \pm 3.7$ & $2.2 \pm 3.1$ & 0.345 \\
\hline 6-min walk test $(\mathrm{m})$ & $430.3 \pm 170.3$ & $458 \pm 180.9$ & $395.8 \pm 150.8$ & 0.031 \\
\hline Index Disease Severity (IDS) score & $3.7 \pm 2.5$ & $2.7 \pm 2.1$ & $4.9 \pm 2.3$ & 0.345 \\
\hline GDS score & $7.4 \pm 5.2$ & $7.1 \pm 5.2$ & $7.7 \pm 5.3$ & 0.493 \\
\hline Third heart sound & $5 \%$ & $7 \%$ & $3 \%$ & 0.259 \\
\hline Peripheral edema & $16.9 \%$ & $10 \%$ & $24 \%$ & 0.016 \\
\hline Jugular vein distention & $11.9 \%$ & $11.9 \%$ & $12.1 \%$ & 0.989 \\
\hline Pericardial fat (mm) & $7.9 \pm 3.1$ & $7.2 \pm 2.8$ & $8.4 \pm 3.4$ & 0.041 \\
\hline Myocardial mass & $129.6 \pm 35.3$ & $130.2 \pm 33,9$ & $128.9 \pm 37.3$ & 0.835 \\
\hline Ejection fraction (\%) & $43.9 \pm 15$ & $41.3 \pm 14.5$ & $47.3 \pm 15.6$ & 0.017 \\
\hline Trans-tricuspid gradient $(\mathrm{mmHg})$ & $19.9 \pm 13.6$ & $21 \pm 14$ & $18.5 \pm 12.9$ & 0.263 \\
\hline Glycaemia (mg/dl) & $118.5 \pm 45$ & $94.5 \pm 11.9$ & $149.7 \pm 52.7$ & 0.001 \\
\hline Hemoglobin (g/dl) & $13.6 \pm 1.5$ & $13.7 \pm 1.5$ & $13.4 \pm 1.5$ & 0.202 \\
\hline HbA1c (\%) & $6.64 \pm 1.27$ & $5.9 \pm 0.3$ & $7.6 \pm 1.4$ & 0.001 \\
\hline eGFR (ml/min) & $71.3 \pm 25.1$ & $67.8 \pm 21.2$ & $75.8 \pm 28.8$ & 0.058 \\
\hline Total cholesterol (mg/dl) & $170.1 \pm 41.8$ & $171.9 \pm 39.6$ & $167.9 \pm 44.7$ & 0.576 \\
\hline $\mathrm{HDL}(\mathrm{mg} / \mathrm{dl})$ & $43.8 \pm 11.5$ & $43.1 \pm 10.3$ & $44.8 \pm 13$ & 0.363 \\
\hline ESR $(\mathrm{mm} / \mathrm{h})$ & $33 \pm 25.2$ & $36.1 \pm 27.4$ & $29.1 \pm 21.6$ & 0.101 \\
\hline TSH (mU/l) & $2.1 \pm 3.7$ & $2.9 \pm 4.2$ & $2.2 \pm 3$ & 0.786 \\
\hline Albumin (g/dl) & $5.1 \pm 0.8$ & $3.9 \pm 0.4$ & $3.7 \pm 0.4$ & 0.147 \\
\hline NT-proBNP (ng/ml) & $2101.9 \pm 4246.6$ & $2066.8 \pm 3243.2$ & $2071.4 \pm 5300.1$ & 0.995 \\
\hline ACE/ARB & $89.5 \%$ & $88 \%$ & $93.9 \%$ & 0.222 \\
\hline Beta-blockers & $82.2 \%$ & $86.9 \%$ & $78.8 \%$ & 0.185 \\
\hline Digitalis & $19.7 \%$ & $19 \%$ & $21.2 \%$ & 0.742 \\
\hline Aldosterone blockers & $25 \%$ & $33.3 \%$ & $15.2 \%$ & 0.011 \\
\hline Loop diuretics & $53.3 \%$ & $52.4 \%$ & $56.1 \%$ & 0.654 \\
\hline Nitrates & $29.6 \%$ & $31 \%$ & $28.8 \%$ & 0.774 \\
\hline Statins & $78.3 \%$ & $85.7 \%$ & $71.2 \%$ & 0.029 \\
\hline Warfarin & $15.1 \%$ & $15.5 \%$ & $15.2 \%$ & 0.956 \\
\hline Aspirin & $84.2 \%$ & $88 \%$ & $81.8 \%$ & 0.281 \\
\hline Clopidogrel & $40.1 \%$ & $50 \%$ & $28.8 \%$ & 0.009 \\
\hline
\end{tabular}

Abbreviations: BMI, Body Mass Index; ACS, Acute Coronary Syndrome; PTCA, Percutaneous Transluminal Coronary Angioplasty; CABG, Coronary Artery Bypass Graft; COPD, Chronic Obstructive Pulmonary Disease; GDS, Geriatric Depression Scale; HbA1c, Glycated Hemoglobin; eGFR, estimated Glomerular Filtration Rate; ESR, Erythrocyte Sedimentation Rate; TSH, Thyroid Stimulating Hormone; ACE/ARB, Angiotensin Converting Enzyme/ACE Receptor Blockers. 


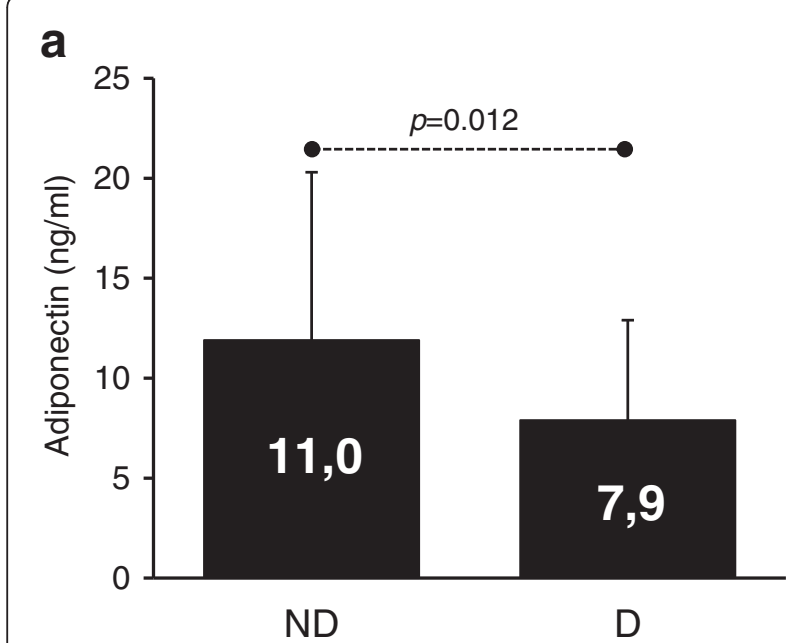

b

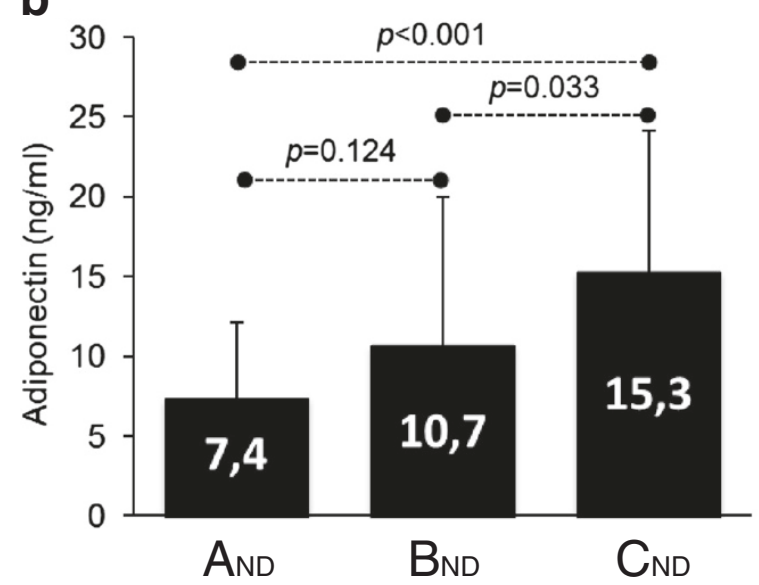

C

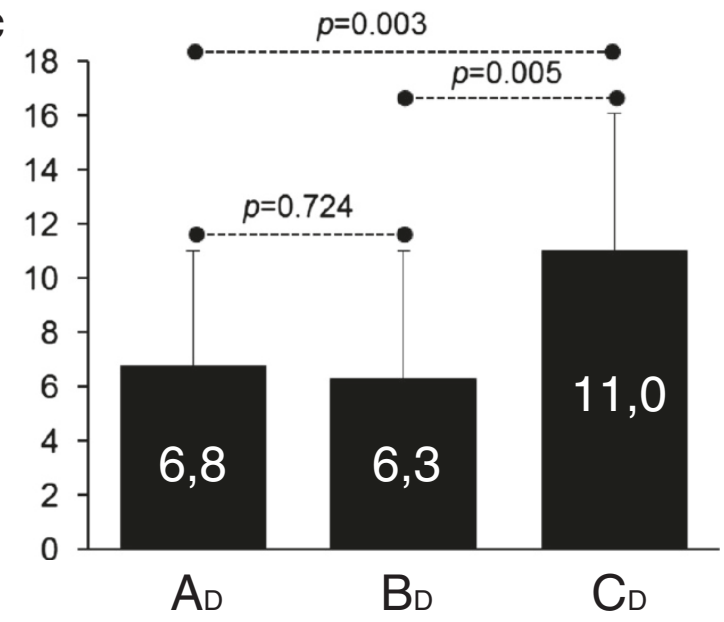

Figure 2 Comparison of adiponectin levels in Non-Diabetic (ND) vs. Diabetic groups (a), and across different clinical stages (A, B and C) of HF, separately in ND and D (b and c).

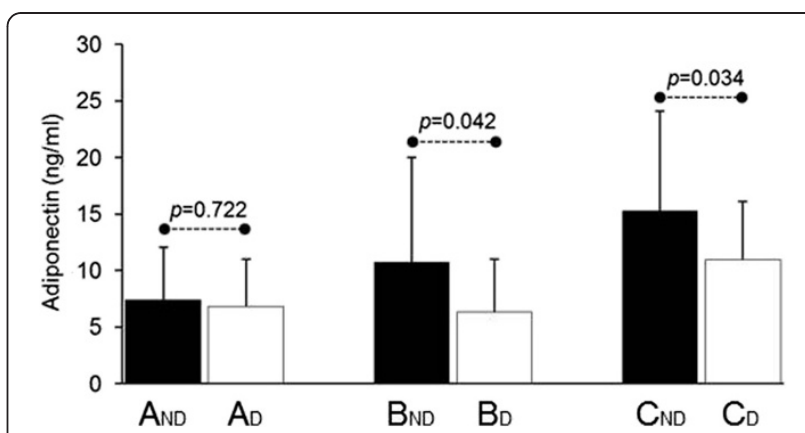

Figure 3 Comparison of adiponectin levels in subjects belonging to the same clinical stage of $\mathrm{HF}(A, B$ and $C)$ but with different metabolic profile (ND, Non-Diabetics vs. D, Diabetics).

(Table 2). Conversely, in the diabetic group the difference after covariate adjustment was not significant.

\section{Independent predictors of AD}

In order to elucidate the predictive value of each variable on $\mathrm{AD}$ level we drew different backward stepwise linear regression models (Table 3). The first model which included age, gender, ACC/AHA clinical stage of HF and the presence of diabetes, showed high predictive strength $(\mathrm{R}=0.62, \mathrm{p}<0.001)$. In the second model we added NT-proBNP; as the first one, it showed a good predictive strength $(\mathrm{R}=0.63, \mathrm{p}<0.001)$. In the third and fourth models we introduced BMI first and then HDL cholesterol; the predictive strength of these models was still satisfactory $(\mathrm{R}=0.62, \mathrm{p}<0.001 ; \mathrm{R}=0.69, \mathrm{p}<0.001$ respectively); however, diabetes lost its independent predictivity.

\section{Discussion}

It is known that plasma levels of $\mathrm{AD}$ are able to predict diabetes onset and diabetic patients show lower concentrations of the adipokine compared to the general population $[4,6]$. Our study extends these observations to a specific subgroup of DM patients with ischemic chronic heart failure, exploring the controversial relationship that exists between AD and HF.

Table 2 Analysis of variance of adiponectin plasma levels across the three subgroups (A, B and C)

\begin{tabular}{lccccc}
\hline Model & \multicolumn{2}{c}{ Unadjusted } & & \multicolumn{2}{c}{ Adjusted* $^{*}$} \\
\cline { 2 - 3 } \cline { 6 - 6 } & $\mathbf{F}$ & $\boldsymbol{p}$ & & $\mathbf{F}$ & $\boldsymbol{p}$ \\
\hline Total poulation & 10.9 & $<0.001$ & & 5.4 & 0.005 \\
ND group & 6.7 & 0.002 & & 6.1 & 0.004 \\
D group & 6.0 & 0.004 & & 1.4 & 0.250 \\
\hline
\end{tabular}

*adjusted for BMI, HDL cholesterol and NT-proBNP.

Abbreviations: ND and D, Non-diabetic and Diabetic group; BMI, Body Mass Index. 
Table 3 Backward stepwise linear regression models

\begin{tabular}{|c|c|c|c|c|c|c|c|c|}
\hline & \multicolumn{2}{|c|}{ Model 1} & \multicolumn{2}{|c|}{ Model 2} & \multicolumn{2}{|c|}{ Model 3} & \multicolumn{2}{|c|}{ Model 4} \\
\hline & \multicolumn{2}{|c|}{$\mathrm{R}=0.62,<0.001$} & \multicolumn{2}{|c|}{$\mathrm{R}=0.63,<0.001$} & \multicolumn{2}{|c|}{$\mathrm{R}=0.63,<0.001$} & \multicolumn{2}{|c|}{$\mathrm{R}=0.69,<0.001$} \\
\hline & $\mathrm{B} \pm \mathrm{SE}$ & $p$ & $\mathrm{~B} \pm \mathrm{SE}$ & $p$ & $\mathrm{~B} \pm \mathrm{SE}$ & $p$ & $\mathrm{~B} \pm \mathrm{SE}$ & $p$ \\
\hline Age & $0.24 \pm 0.05$ & $<0.001$ & $0.17 \pm 0.05$ & $<0.001$ & $0.10 \pm 0.05$ & 0.021 & $0.07 \pm 0.04$ & 0.124 \\
\hline Gender & $5.70 \pm 1.51$ & $<0.001$ & $4.05 \pm 1.49$ & 0.008 & $4.49 \pm 1.41$ & 0.002 & $1.97 \pm 1.47$ & 0.182 \\
\hline ACC/AHA stage & $2.47 \pm 0.60$ & $<0.001$ & $1.77 \pm 0.62$ & 0.005 & $1.38 \pm 0.60$ & 0.023 & $1.40 \pm 0.57$ & 0.016 \\
\hline Diabetes & $-3.44 \pm 0.99$ & 0.001 & $-2.90 \pm 0.95$ & 0.003 & $-1.37 \pm 1.02$ & 0.182 & $-1.86 \pm 0.98$ & 0.061 \\
\hline NT-proBNP & & & $0.01 \pm 0.01$ & 0.001 & $0.01 \pm 0.01$ & $<0.001$ & $0.01 \pm 0.01$ & $<0.001$ \\
\hline BMI & & & & & $-0.30 \pm 0.11$ & 0.008 & $-0.17 \pm 0.12$ & 0.164 \\
\hline HDL cholesterol & & & & & & & $0.17 \pm 0.04$ & $<0.001$ \\
\hline
\end{tabular}

Abbreviations: ACC/AHA, American College of Cardiology/American Heart Association; BMI, Body Mass Index.

This study confirms our previous observation that $\mathrm{AD}$ increases in patients with CAD and overt HF compared to those with normal or reduced LVEF but clinically asymptomatic [19]. This is in accordance to the literature which reports higher $\mathrm{AD}$ levels in patients with advanced NYHA class [13]. We now show that not only clinical staging, but also a more pathophysiological classification of $\mathrm{HF}$ as proposed by ACC/AHA guidelines, is able to predict $A D$ levels in this subset of patients. NT-proBNP, HDL cholesterol and age still remain the strongest, independent predictors of AD [19].

We have shown that $\mathrm{AD}$ levels are systematically lower in diabetics compared to non-diabetics, no matter to what HF staging class they belong. These data suggest that diabetic subjects with reduced LVEF orchestrate a slower rise of $A D$ which begins only in face of overt HF (group $C_{D}$ ). It is of interest that Chen and coll. in asymptomatic men with uncomplicated type 2 diabetes found a positive association of circulating AD levels with myocardial glucose metabolism but not with cardiac function [30].

Because of its cross-sectional nature, our study cannot elucidate with clarity the pathophysiological mechanisms that lie under the increase of AD at worsening HF. In any case, some considerations can arise from the data. First of all, cardiac cachexia cannot be the main cause of higher AD levels in HF because none of our study subjects was underweight and the increase of $A D$ observed between $\mathrm{A} / \mathrm{B}$ and $\mathrm{C}$ was not coupled to a decrease of BMI. Therefore, cardiac cachexia is a late process in HF compared to the increase of $\mathrm{AD}$ which seems to be a faster phenomenon.

For the same reason, we cannot offer a definite explanation for the hampered rise of $\mathrm{AD}$ that we detected in $\mathrm{HF}$ diabetic subjects. However, we can speculate that diabetics have lower $\mathrm{AD}$ plasma levels to begin with which may depend from their higher BMI. Indeed, in our backward stepwise linear regression models, we found that DM loses its predictivity on $\mathrm{AD}$ when $\mathrm{BMI}$ was introduced as cofactor. However, if we focus on patients with overt $\mathrm{HF}\left(\mathrm{C}_{\mathrm{ND}}\right.$ vs. $C_{D}$ ) we find that despite a significant difference in $A D$ levels, BMI was not different (data not shown). These data suggest that something else, beyond body weight, is able to modulate adiponectin metabolism in diabetic patients with HF. A good candidate could be NT-proBNP which seems to directly induce AD production by adipocytes, in vitro, and in heart failure patients [17]. Even more striking, natriuretic peptides are able to increase total and HMW-adiponectin concentrations in healthy subjects [31]. It could be assumed that diabetic patients produce lower levels of NT-proBNP in response of overt HF. However, this is not the case: in fact the level of NTproBNP is not significantly different between diabetics and non-diabetics belonging to the $\mathrm{A}$ and $\mathrm{B}$ clinical stages. Even more, diabetic subjects in the $\mathrm{C}$ group have higher, although not significant, levels of NT-proBNP when compared to the non-diabetic $C$ subgroup, in spite of a lower adiponectinemia (data not shown). A question remains as to what lies between the secretion of NTproBNP and the production of AD by adipocytes. Some sort of "NT-proBNP resistance" may exist in type 2 DM. Further studies will be required to investigate this hypothesis, comparing the different $\mathrm{AD}$ response of diabetic and non-diabetic subjects to injection of natriuretic peptides.

Finally, Won and coll. found that plasma concentration of $\mathrm{AD}$ was significantly lower in HF patients with metabolic syndrome compared to HF patients without metabolic syndrome [32]. In our series, the prevalence of metabolic syndrome, as defined by ATPIII criteria $[33,34]$, was $68.2 \%$ in diabetic patients and $30.9 \%$ in nondiabetic patients. At multivariate analysis, the presence of metabolic syndrome was not an independent predictor of $\mathrm{AD}$ plasma levels (data not shown).

\section{Study limitations}

Our population comprises only ischemic HF and type 2 DM. Heart failure of different etiology (valvular, hypertensive and idiopathic) was not explored. Similarly, we have no data regarding type $1 \mathrm{DM}$. Another limitation of the study is the small number of female subjects (only 13\%) that were included which depended on the nature of the inclusion 
criteria (CAD). Finally, as stated above, all limitations of cross sectional studies also apply to our findings.

\section{Conclusion}

We corroborate the finding that $\mathrm{AD}$ raises across the ACC/AHA chronic HF stages but this is less evident in diabetic patients. In type $2 \mathrm{DM}$ the progressive increase of $\mathrm{AD}$ in relation to the severity of LV dysfunction is hampered and becomes evident only in overt HF. The different adipokine profile seems to be partially, but not exclusively, determined by the well-known predictors of $\mathrm{AD}$. Other molecular mechanisms, such as a "NT-proBNP resistance", acting in diabetic patients, can be hypothesized to explain the different behavior of this adipokine.

\begin{abstract}
Abbreviations
ACC/AHA: American College of Cardiology/American Heart Association; AD: Adiponectin; BMI: Body Mass Index; CAD: Coronary Artery Disease; DM: Diabetes Mellitus; D and ND: Diabetic and Non-Diabetic group; eGFR: Estimated glomerular filtration rate; GDS: Geriatric Depression Scale; Hb: Hemoglobin; HbA1c: Glycated Hb; HF: Heart Failure; IDS: Greenfield's Index of Disease Severity; LVEF: Left Ventricular Ejection Fraction; 6MWT: 6min walking test; NYHA: New York Heart Association.
\end{abstract}

\section{Competing interest}

The Authors declare that they have no competing interests.

\section{Authors' contributions}

SB and FT conceptualized and designed the study and carried out the analysis and interpretation of data; NM contributed to the design of the study and the interpretation of data; AA, FO, NB, AF, AM, AP, and SS participated to the acquisition and analysis of data; CDS and GL carried out the biochemical analysis including the determination of adiponectin; SF and MM performed the statistical analysis; EM gave an important intellectual contribution by revising the manuscript critically. All authors read and approved the final manuscript.

Received: 19 October 2012 Accepted: 1 December 2012 Published: 18 December 2012

\section{References}

1. Ahima RS, Flier JS: Adipose tissue as an endocrine organ. Trends Endocrin Met 2000, 11:327-332.

2. Lau DCW, Dhillon B, Yan H, Szmitko PE, Verma S: Adipokines: molecular links between obesity and atheroslcerosis. Am J Physiol Heart Circ Physiol 2005, 288:H2031-H2041.

3. Arita Y, Kihara S, Ouchi N, Takahashi M, Maeda K, Miyagawa J, Hotta K, Shimomura I, Nakamura T, Miyaoka K, Kuriyama H, Nishida M, Yamashita S, Okubo K, Matsubara K, Muraguchi M, Ohmoto Y, Funahashi T, Matsuzawa Y: Paradoxical decrease of an adipose-specific protein, adiponectin, in obesity. Biochem Biophys Res Commun 1999, 257:79-83.

4. Kadowaki T, Yamauchi T, Kubota N, Hara K, Ueki K, Tobe K: Adiponectin and adiponectin receptors in insulin resistance, diabetes, and the metabolic syndrome. J Clin Invest 2006, 116:1784-1792.

5. Yamauchi T, Kamon J, Minokoshi Y, Ito Y, Waki H, Uchida S, Yamashita S, Noda M, Kita S, Ueki K, Eto K, Akanuma Y, Froguel P, Foufelle F, Ferre P, Carling D, Kimura S, Nagai R, Kahn BB, Kadowaki T: Adiponectin stimulates glucose utilization and fatty-acid oxidation by activating AMP-activated protein kinase. Nat Med 2002, 8:1288-1295.

6. Hotta K, Funahashi T, Bodkin NL, Ortmeyer HK, Arita Y, Hansen BC Matsuzawa Y: Circulating concentrations of the adipocyte protein adiponectin are decreased in parallel with reduced insulin sensitivity during the progression to type 2 diabetes in rhesus monkeys. Diabetes 2001, 50:1126-1133.

7. Tuttolomondo A, La Placa S, Di Raimondo D, Bellia C, Caruso A, Lo Sasso B, Guercio G, Diana G, Ciaccio M, Licata G, Pinto A: Adiponectin, resistin and IL-6 plasma levels in subjects with diabetic foot and possible correlations with clinical variables and cardiovascular co-morbidity. Cardiovasc Diabetol 2010, 9:50.

8. Jansson PA, Pellmé F, Hammarstedt A, Sandqvist M, Brekke H, Caidahl K, Forsberg M, Volkmann R, Carvalho E, Funahashi T, Matsuzawa Y, Wiklund O, Yang X, Taskinen MR, Smith U: A novel cellular marker of insulin resistance and early atherosclerosis in humans is related to impaired fat cell differentiation and low adiponectin. FASEB J 2003, 17:1434-1440.

9. Han SH, Quon MJ, Kim J, Koh KK: Adiponectin and cardiovascular disease: response to therapeutic interventions. J Am Coll Cardiol 2007, 49:531-538.

10. Barseghian A, Gawande D, Bajaj M: Adiponectin and vulnerable atherosclerotic plaques. J Am Coll Cardiol 2011, 57:761-770.

11. Ouchi N, Shibata R, Walsh K: Cardioprotection by adiponectin. Trends Cardiovasc Med 2006, 16:141-146.

12. George J, Patal S, Wexler D, Sharabi Y, Peleg E, Kamari Y, Grossman E, Sheps $D$, Keren G, Roth A: Circulating adiponectin concentrations in patients with congestive heart failure. Heart 2006, 92:1420-1424.

13. Nakamura T, Funayama H, Kubo N, Yasu T, Kawakami M, Saito M, Momomura S, Ishikawa SE: Association of hyperadiponectinemia with severity of ventricular dysfunction in congestive heart failure. Circ J 2006, 70:1557-1562.

14. Kistorp C, Faber J, Galatius S, Gustafsson F, Frystyk J, Flyvbjerg A, Hildebrandt P: Plasma adiponectin, body mass index, and mortality in patients with chronic heart failure. Circulation 2005, 112:1756-1762.

15. McEntegart MB, Awede B, Petrie MC, Sattar N, Dunn FG, MacFarlane NG, McMurray JJ: Increase in serum adiponectin concentration in patients with heart failure and cachexia: relationship with leptin, other cytokines, and B-type natriuretic peptide. Eur Heart J 2007, 28:829-835.

16. Van Berendoncks AM, Garnier A, Beckers P, Hoymans WY, Possemiers N, Fortin D, Martinet W, Van Hoof V, Vrints CJ, Ventura-Clapier R, Conraads VM: Functional adiponectin resistance at the level of the skeletal muscle in mild to moderate chronic heart failure. Circ Heart Fail 2010, 3:185-194.

17. Tsukamoto O, Fujita M, Kato M, Yamazaki S, Asano Y, Ogai A, Okazaki H, Asai M, Nagamachi Y, Maeda N, Shintani Y, Minamino T, Asakura M, Kishimoto I, Funahashi T, Tomoike H, Kitakaze M: Natriuretic peptides enhance the production of adiponectin in human adipocytes and in patients with chronic heart failure. J Am Coll Cardiol 2009, 53:2070-2077.

18. Park M, Sweeney G: Direct effects of adipokines on the heart: focus on adiponectin. Heart Fail Rev 2012: [Epub ahead of print].

19. Baldasseroni S, Mannucci E, Orso F, Di Serio C, Pratesi A, Bartoli N, Marella GA, Colombi C, Foschini A, Valoti P, Mossello E, Fumagalli S, Marchionni N, Tarantini F: Adiponectin in outpatients with coronary artery disease: independent predictors and relationship with heart failure. Nutr Metab Cardiovasc Dis 2012, 22:292-299.

20. American Diabetes Association: Diagnosis and classification of diabetes mellitus. Diabetes Care 2009, 33(Supp. 1):S62-S69.

21. Guyatt GH, Sullivan MJ, Thompson PJ, Fallen EL, Pugsley SO, Taylor DW, Berman LB: The 6-min walk: a new measure of exercise capacity in patients with chronic heart failure. Can Med Assoc J 1985, 132:919-923.

22. Picard MH, Adams D, Bierig SM, Dent JM, Douglas PS, Gillam LD, Keller AM, Malenka DJ, Masoudi FA, McCulloch M, Pellikka PA, Peters PJ, Stainback RF, Strachan GM, Zoghbi WA: American Society of Echocardiography recommendations for quality echocardiography laboratory operations. J Am Soc Echocardiogr 2011, 24:1-10.

23. Dickstein K, Cohen-Solal A, Filippatos G, McMurray JJV, Ponikowski P, PooleWilson PA, Strömberg A, van Veldhuisen DJ, Atar D, Hoes AW, Keren A, Mebazaa A, Nieminen M, Priori SG, Swedberg K, ESC Committee for Practice Guidelines (CPG): ESC Guidelines for the diagnosis and treatment of acute and chronic heart failure 2008: the Task Force for the Diagnosis and Treatment of Acute and Chronic Heart Failure 2008 of the European Society of Cardiology. Developed in collaboration with the Heart Failure Association of the ESC (HFA) and endorsed by the European Society of Intensive Care Medicine (ESICM). Eur Heart J 2008, 29:2388-2442.

24. Carlson KJ, Lee DC, Goroll AH, Leahy M, Johnson RA: An analysis of physicians' reasons for prescribing long-term digitalis therapy in outpatients. J Chronic Dis 1985, 38:733-739.

25. Jessup M, Abraham WT, Casey DE, Feldman AM, Francis GS, Ganiats TG, Konstam MA, Mancini DM, Rahko PS, Silver MA, Stevenson LW, Yancy CW: 2009 Focused Update: ACCF/AHA Guidelines for the Diagnosis and Management of Heart Failure in Adults: a report of the American College of Cardiology Foundation/American Heart Association task force on practice guidelines: developed in collaboration with the international 
society for heart and lung transplantation. Circulation 2009, 119:1977-2016.

26. Greenfield S, Blanco S, Elashoff RM, Ganz PA: Development and testing of a new index of comorbidity. Clin Res 1987, A35:346

27. Yesavage JA, Brink TL, Rose TL, Lum O, Huang V, Adey M, Leirer VO: Development and validation of a geriatric depression screening scale: a preliminary report. J Psychiatr Res 1982, 17:37-49.

28. Levey AS, Bosch JP, Lewis JB, Greene T, Rogers N, Roth D: A more accurate method to estimate glomerular filtration rate from serum creatinine: a new prediction equation. Modification of diet in renal disease study group. Ann Intern Med 1999, 130:461-470.

29. lacobellis G, Assael F, Ribaudo MC, Zappaterreno A, Alessi G, Di Mario U, Leonetti F: Epicardial fat from echocardiography: a new method for visceral adipose tissue prediction. Obes Res 2003, 11:304-310.

30. Chen WJY, Rijzewijk LJ, van der Meer RW, Heymans MW, van Duinkerken E, Lubberink M, Lammertsma AA, Lamb HJ, de Roos A, Romijn JA, Smit JWA, Bax JJ, Bjerre M, Frystyk J, Flyvbjerg A, Diamant M: Association of plasma osteoprotegerin and adiponectin with arterial function, cardiac function and metabolism in asymptomatic type 2 diabetic men.

Cardiovasc Diabetol 2011, 10:67.

31. Birkenfeld AL, Boschmann M, Engeli S, Moro C, Arafat AM, Luft FC, Jordan J: Atrial natriuretic peptide and adiponectin interactions in man. PLoS One 2012, 7:e43238.

32. Won H, Kang SM, Shin MJ, Oh J, Hong N, Park S, Lee SH, Jang Y, Chung N: Plasma adiponectin concentration and its association with metabolic syndrome in patients with heart failure. Yonsei Med J 2012, 53:91-98.

33. : Third report of the National Cholesterol Education Program (NCEP) expert panel on detection, evaluation, and treatment of high blood cholesterol in adults (Adult Treatment Panel III). Final report. Circulation 2002, 106:3143-3421.

34. Grundy SM, Brewer HB Jr, Cleeman Jl, Smith SC Jr, Lenfant C, for the Conference Participants: Definition of metabolic syndrome. Report of the national heart, lung, and blood Institute/American heart association conference on scientific issues related to definition. Circulation 2004, 109:433-438.

doi:10.1186/1475-2840-11-151

Cite this article as: Baldasseroni et al: Adiponectin, diabetes and ischemic heart failure: a challenging relationship. Cardiovascular Diabetology 2012 11:151.

\section{Submit your next manuscript to BioMed Central and take full advantage of:}

- Convenient online submission

- Thorough peer review

- No space constraints or color figure charges

- Immediate publication on acceptance

- Inclusion in PubMed, CAS, Scopus and Google Scholar

- Research which is freely available for redistribution 